\title{
PENGARUH KECERDASAN EMOSIONAL DAN KEPUASAN KERJA TERHADAP PERILAKU KEWARGAAN ORGANISASI PADA BADAN KEPEGAWAIAN DAERAH PROVINSI JAWA BARAT DI BANDUNG
}

\author{
Nadya Mahri \\ Universitas Pendidikan Indonesia \\ mahrinadya@student.upi.edu \\ Bambang Widjajanta \\ Universitas Pendidikan Indonesia \\ Sumiyati \\ Universitas Pendidikan Indonesia
}

\begin{abstract}
ABSTRAK
Tujuan - Tujuan penelitian ini yaitu untuk melihat pengaruh kecerdasan emosional, kepuasan kerja dan perilaku kewargaan organisasi.

Desain/metodologi/pendekatan - Desain penelitian ini adalah cross sectional method. Penelitian ini menggunakan pendekatan deskriptif dengan metode explanatory survei. Sebanyak 103 responden dipilih dengan menggunakan probability sampling. Sebuah angket digunakan sebagai instrumen penelitian untuk mengumpulkan data dari responden. Teknik analisis yang digunakan adalah teknik deskriptif dengan menggunakan distribusi frekuensi.

Temuan - Berdasarkan hasil penelitian menggunakan analisis deskriptif, didapatkan hasil bahwa kecerdasan emosional dalam katagori baik dengan skor 9444 diperoleh persentase sebesar $81,86 \%$, kepuasan kerja dalam katagori tinggi dengan skor 12198 diperoleh persentase sebesar 80,56\%. dan perilaku kewargaan organisasi berada dalam kategori baik dengan skor 11853 diperoleh persentase sebesar 82,19\%.

Orisinalitas/nilai - Penelitian ini sebagai dasar untuk memahami konsep kecerdasan emosional, kepuasan kerja dan perilaku kewargaan organisasi. Perbedaan penelitian ini dengan penelitian

sebelumnya terletak pada objek yaitu pada Badan Kepegawaian Daerah Provinsi Jawa Barat di Bandung dengan variabel yang diteliti yaitu kecerdasan

emosional, kepuasan kerja, perilaku kewargaan organisasi serta menggunakan teori atau referensi yang berbeda dengan peneliti sebelumnya.
\end{abstract}

Kata Kunci: Kecerdasan Emosional, Kepuasan Kerja dan Perilaku Kewargaan Organisasi

Jenis Artikel: Studi Kasus

\begin{abstract}
ABSTRACK
Aim - The aim of the research was to find out the influence of emotional intelligence, job satisfaction, and organizational citizenship behavior.

Design/Methodology/Approach - The research design was cross sectional method. This research employed descriptive approach through explanatory survey method. There were 103 respondents selected through probability sampling. The questionnaires were distributed as the instruments in collecting data from the respondents. The analysis technique used was descriptive technique by using frequency distribution.

Findings - Based on the research findings through descriptive analysis, it was found that the emotional intelligence was in the good category by score 9444 and percentage $81.86 \%$, job satisfaction was in high category by score 12198 and percentage $80.56 \%$, and organizational citizenship behavior was in the good category by score 11853 and percentage $82.19 \%$.

Originality/value - This research is the basic to understand the emotional intelligence, job satisfaction, and organizational citizenship behavior concept. The difference of the research and the previous research was in its object aspect, which was West Java Regional Civil Service Agency in Bandung with the observed variables; emotional intelligence, job satisfaction, organizational citizenship behavior by using different theories and references from previous research.
\end{abstract}

Keyword: Emotional Intelligence, Job Satisfaction and Organizational citizenship behavior

Type of arcticle: case study 


\section{PENDAHULUAN}

Pentingnya perilaku kewargaan yang baik di dalam organisasi, menjadi prioritas tinggi suatu organisasi dalam menyeleksi pegawai. (Ayim \& Haybatollahi, 2015). Pegawai yang memiliki perilaku kewargaan organisasi cenderung melampaui tugasnya, menjadi relawan untuk mengambil tanggung jawab lebih demi kemajuan organisasi (Bolino, Harvey, \& Lepine, 2015), selain itu menjadikan organisasi sebagai tempat yang menarik untuk bekerja merupakan hal yang positif (Bolino et al., 2015). Pegawai di dalam organisasi merupakan prioritas yang perlu dihadapi, (Sumiyati, Masharyono, Kevin Fajar Pratama \& Ridwan Purnama, 2016), sehingga memaksimalkan kinerja pegawai menjadi tantangan utama dalam suatu organisasi. (Syamsul Hadi Senen, Masharyono, Sumiyati \& Nida Triananda, 2016). Efektivitas dan efisiensi tidak akan berarti jika pencapaian tujuan dalam organisasi tidak ada dukungan dari sumber daya manusia yang berkualitas. (Masharyono, Sumiyati, Toyib, 2016). Kebanyakan hal yang dapat mempengaruhi kualitas tenaga kerja pegawai, salah satunya dukungan dari lingkungan kerjanya. (Sumiyati, Masharyono, Ridwan, Kevin, 2016).

Organisasi sadar pentingnya perilaku kewargaan organisasi adalah salah satu faktor keberhasilan dalam membantu pengembangan organisasi. (Ebrahimpour, Zahed, Khaleghkhah, \& Bager, 2011). Organisasi membutuhkan ide dan pendapat dari pegawai mengenai hal yang menjadi perhatian di tempat kerja, karena pegawai melihat banyak hal ketika melakukan pekerjaan. (Putri Rahmawati, Sumiyati, \& Masharyono, 2016). Pengembangan organisasi menjadi tantangan yang dihadapi pemimpin yaitu menciptakan perilaku kewargaan organisasi yang sukarela melakukan tugasnya dan mempunyai komitmen dengan tujuan organisasi. (Eyvind Elstad, Knut-Andreas Christophersen, 2012). Implementasi organisasi dapat ditentukan oleh produktivitas pegawai untuk mencapai tujuan yang telah ditentukan. (Syamsul, Sumiyati, Masharyono, 2016).

Perilaku kewargaan organisasi sering dikaitkan pada organisasi di bidang jasa, salah satunya pada Pegawai Negeri Sipil atau aparatur Negara. Objek penelitian yang ingin diteliti yaitu pada Badan Kepegawaian Daerah (BKD) Provinsi Jawa Barat. Badan Kepegawaian Daerah merupakan perangkat daerah yang menjalankan manajemen Pegawai Negeri Sipil daerah dalam meningkatkan efektivitas, efisiensi, dan profesionalisme penyelenggaraan tugas, fungsi dan kewajiban pegawai, yang meliputi pengembangan kualitas, perencanaan, promosi, penempatan, penggajian, kesejahteraan, dan pemberhentian pegawai. Laporan tahunan Badan Kepegawaian Daerah Provinsi Jawa Barat telah menunjukkan salah satu upaya untuk meningkatkan perilaku kewargaan organisasi dengan meningkatkan kecerdasan emosional dan kepuasan kerja, sehingga pegawai merasa nyaman dan mempunyai loyalitas yang tinggi terhadap organisasi.

Sumber : Bagian Kepegawaian dan Umum BKD Prov Jabar.

Sumber daya manusia tetap menjadi satu bagian penting dalam organisasi, oleh karena itu pegawai bekerja sesuai dengan tugas dan tanggung jawab yang dibebankan kepadanya. (Masharyono \& Syamsul Hadi Senen, 2015). Peranan sumber daya manusia yang ada pada sebuah organisasi semakin penting seiring dengan semakin kompleksnya tugas, tanggung jawab, dan tantangan yang dihadapi organisasi saat ini. (Masharyono, 2015). Perilaku kewargaan organisasi memiliki efek positif secara keseluruhan di dalam organisasi (Zeinabadi, 2010). Perilaku kewargaan organisasi berorientasi terhadap berbagi pengetahuan kepada rekan kerja di kalangan pegawai negeri untuk memajukan organisasi (Tuan, 2016). Permasalahan perilaku pegawai harus diperhatikan dan dikelola dalam rangka menghindari dampak buruk seperti keterlambatan yang dapat menurunkan kualitas kerja, merusak organisasi dan kinerja pegawai lainnya (Sabahi \& Dashti, 2016).

Perilaku kewargaan organisasi menurun, akan berdampak negatif terhadap organisasi. Dampak yang akan terjadi yaitu fluktuasi penurunan dan kenaikan tingkat keterlambatan pegawai, absensi pegawai, pegawai pulang tidak tepat waktu tanpa izin. Keterlambatan pegawai cenderung mengalami kenaikan, banyak pegawai yang ijin dan tidak masuk kerja tanpa keterangan, serta pegawai yang pulang kerja tidak tepat waktu tanpa izin, hal ini berkaitan erat dengan disiplin kerja pegawai yang mengakibatkan lemahnya loyalitas terhadap organisasi.

Solusi dari perilaku kewargaan organisasi, pertama yaitu kecerdasan emosional, dalam penelitian yang dilakukan oleh Amir Hoshang Sabahi dan Naser Sanai Dashti (2016) menyatakan bahwa hubungan kecerdasan emosional dan dua karakteristik perilaku kewargaan organisasi yaitu altruisme dan kepatuhan merupakan hubungan yang positif terhadap hasil kerja pegawai (Sabahi \& Dashti, 2016).

Solusi kedua yaitu kepuasan kerja, penelitian dilakukan oleh Hassanreza Zeinabadi (2010) menyatakan bahwa kepuasan kerja berhubungan positif dengan perilaku kewargaan organisasi, pegawai yang puas dari pekerjaannya akan membalas perilaku positif dan memberikan umpan balik yang positif terhadap organisasi (Zeinabadi, 2010), strategi yang dilakukan organisasi untuk meningkatkan kepuasan kerja karyawan salah satunya dengan memberikan 
kompensasi, reward, rekreasi bersama, maka secara tidak langsung pegawai akan merasa nyaman dan timbul rasa peduli untuk memajukan organisasi.

Tujuan penelitian ini yaitu untuk melihat pengaruh kecerdasan emosional, kepuasan kerja dan perilaku kewargaan organisasi.

\section{KAJIAN PUSTAKA}

Perilaku kewargaan organisasi (Organizational Citizenship Behavior) awalnya dikonsepkan oleh (Organ (1988) dalam jurnal (Bolino et al., 2015)), mengacu pada suatu tindakan diskresi yang secara gabungan meningkatkan efektivitas di dalam organisasi, dapat mewujudkan kesejahteraan orang lain dengan sukarela (Brightman, Moran, Brightman, \& Moran, 2011) membantu rekan kerja dalam menyelesaikan tugas, sehingga menciptakan pengetahuan institusional khususnya di bidang perilaku organisasi. (Zellars, Tepper, \& Duffy, 2002) dan (Ebrahimpour, Zahed, Khaleghkhah, \& Bager, 2011).

Penelitian yang dilakukan Organ (1988) memperkenalkan lima dimensi dari Organizational Citizenship Behavior dalam karyanya, yang dikenal sebagai altruisme (kesopanan), conscientiousness, civic virtue dan sportsmanship. Dimensi ini dianggap karakteristik utama menentukan kewarganegaraan karyawan dan komitmen terhadap organisasinya. (Romle, Faezah, Talib, Sabrina, \& Shahuri, 2016).

Konsep perilaku kewargaan organisasi (Organizational Citizenship Behavior) menjadi banyak perhatian dalam bidang manajemen sumber daya manusia, pemasaran, psikologi masyarakat, hukum industri dan tenaga kerja, strategis manajemen, manajemen internasional, psikologi militer, ekonomi, dan kepemimpinan (Philip M Podsakoff, Mackenzie, Paine, \& Bachrach, 2000) (Eyvind Elstad, Knut-Andreas Christophersen, 2012). Banyak penelitian menurut para ahli mengenai konsep perilaku kewargaan organisasi selama tiga dekade terakhir ini. (Philip M Podsakoff et al., 2000).

Konsep perilaku kewargaan organisasi telah memberikan perubahan yang cukup besar di bidang perilaku organisasi (Ebrahimpour, Zahed, Khaleghkhah, \& Bager, 2011), konsep ini menimbulkan organisasi menjadi lebih inovatif, sukses dan fleksibel untuk keberlangsungan hidup dan keberhasilan mereka. (Ebrahimpour, Zahed, Khaleghkhah, \& Bager, 2011). Perilaku pegawai sangat penting dan berpengaruh dalam keefektifan organisasi. (Dhitiporn Chompookum, 2006). Perilaku kewargaan organisasi dikenal sebagai ilmu yang mempelajari perilaku manusia dalam sebuah organisasi dan bagaimana perilaku tersebut mempengaruhi ketika berada dalam organisasi. (Romle et al., 2016).
Grand theory yang digunakan untuk mengatasi permasalahan perilaku kewargaan organisasi, terdapat dalam teori perilaku organisasi dari Stephen P. Robbins. Perilaku organisasi adalah bidang studi yang menyelidiki dampak perorangan, kelompok, dan pengaruh struktur pada perilaku, dengan tujuan untuk menerapkan pengetahuan dalam rangka memperbaiki keefektifan organisasi. Perilaku individu didorong oleh kebutuhan, yaitu beberapa pernyataan dalam diri seseorang yang menyebabkan seseorang itu berbuat untuk mencapainya sebagai objek atau hasil. (Hellriegel \& Slocum, 2011).

Perilaku kewargaan organisasi merupakan perilaku yang bukan bagian dari sebuah persyaratan kerja formal pegawai, memberikan kontribusi untuk psikologis dan lingkungan sosial di tempat kerja, yang disebut perilaku kewargaan. Organisasi yang sukses membutuhkan pegawai yang akan melakukan pekerjaan lebih dari tugas biasanya, yang akan memberikan kinerja yang melampaui harapan. Tempat kerja yang dinamis, dimana tugas-tugas yang semakin banyak akan dilakukan secara bersama-sama oleh tim yang bersifat fleksibel dan kritis. (Sabahi \& Sanai Dashti, 2016).

Pegawai yang terlibat di dalamnya dapat dikatakan good citizenship atau kewargaan yang baik, karena sifat relawan untuk bekerja ekstra, membantu tugas orang lain, menghindari konflik yang tidak perlu, memiliki semangat kerja, serta patuh terhadap peraturan yang berlaku demi kemajuan organisasi. (Robbins \& Judge, 2015).

Organisasi tidak bisa secara efektif bersaing, mengubah sumber daya, atau melayani kebutuhan pemangku kepentingan, jika karyawan hanya dilibatkan hanya pada tugas pekerjaan formal saja. Dengan kata lain, organisasi membutuhkan kinerja kontekstual perilaku kewargaan organisasi bersama dengan kinerja tugas. (McShane \& Glinow, 2010). Perilaku kewargaan organisasi merupakan perilaku-perilaku yang dilakukan secara sukarelamembantu rekan kerjanya di luar tugasperilaku atau diluar tanggung jawab tugasnya yang telah menciptakan gelombang baru di dalam ilmu pengetahuan institusional yang secara khusus ada di bidang perilaku organisasi yang sangat memiliki peran penting dalam untuk meningkatkan efektivitas organisasi dan sesuai dengan tujuan organisasi.

Perilaku kewargaan organisasi yang merupakan tindakan seperti prajurit yang baik, perilaku yang sukarela mengerjakan tugas di luar pekerjaan yang telah ditentukan. Gelombang baru dalam pengetahuan institusional khususnya di bidang perilaku organisasi yang memiliki peran penting dalam efektivitas di organisasi. (Ebrahimpour, Zahed, Khaleghkhah, \& Sepehri, 2011). Dapat dijelaskan bahwa perilaku kewargaan organisasi mengacu meningkatkan efektivitas di 
dalam organisasi, dapat mewujudkan kesejahteraan orang lain dengan sukarela membantu rekan kerja dalam menyelesaikan tugas. Konsep perilaku kewargaan organisasi telah memberikan perubahan di bidang perilaku organisasi selain, menimbulkan organisasi menjadi lebih inovatif, sukses dan fleksibel dalam bertanggung jawab.

Perilaku kewargaan organisasi didasarkan pada lima dimensi menurut (Organ et al., 1989), diantaranya:

1) Alturism

Perilaku pegawai yang menolong rekan kerjanya yang mengalami kesulitan dalam situasi yang sedang dihadapi baik mengenai tugas dalam organisasi maupun masalah pribadi orang lain. Dimensi ini mengarah kepada memberi pertolongan yang bukan merupakan kewajiban yang ditanggungnya.

2) Conscientiousness

Perilaku yang ditunjukkan dengan berusaha melebihi yang diharapkan perusahaan. Perilaku sukarela yang merupakan kewajiban atau tugas pegawai. Misalnya memberikan kinerja melebihi standar minimum dan menyelesaikan tugas sebelum waktunya.

3) Sportmanship

Perilaku yang memberikan toleransi terhadap kebijakan dan keadaan yang kurang ideal dalam organisasi tanpa mengajukan keberatan. Seseorang yang mempunyai tingkatan yang tinggi dalam sportmanship akan meningkatkan hal positif diantara pegawai, sehingga lebih sopan dan bekerjasama dengan yang lain.

4) Courtesy

Menjaga hubungan baik dengan rekan kerjanya agar terhindar dari masalahmasalah interpersonal. Seseorang yang memiliki dimensi ini adalah orang yang menghargai dan memerhatikan orang lain.

5) Civic Virtue

Perilaku yang mengindikasikan kesediaan mengikuti kegiatan diluar pekerjaan dan tanggung jawab pada kehidupan organisasi (mengikuti prosedur dan aturan dalam organisasi, mengikuti perubahan dalam organisasi, dan melindungi sumber-sumber yang dimiliki oleh organisasi).

Dimensi perilaku kewargaan organisasi menurut (P.M. Podsakoff, Mackenzie, Paine, \& Bachrach, 2000) terdiri dari:

1) Helping Behavior (Perilaku Menolong) Bentuk perilaku sukarela individu untuk menolong individu lain atau mencegah terjadinya permasalahan yang terkait dengan pekerjaan (workrelated problem).
2) Sportsmanship

Kemauan atau keinginan untuk menerima (toleransi) terhadap ketidaknyamanan yang muncul dan imposition of work without complaining.

3) Organizational Loyality

Bentuk perilaku loyalitas individu terhadap organisasi yaitu menampilkan imagepositif tentang organisasi, membela organisasi dari ancaman eksternal, mendukung dan membela tujuan organisasi.

4) Organizational Compliance

Bentuk perilaku individu yang mematuhi segala peraturan, prosedur, dan regulasi organisasi meskipun tidak ada pihak yang mengawasi.

5) Individual Initiative

Bentuk self-motivation individu dalam melaksanakan tugas secara lebih baik atau melampaui standar/level yang ditetapkan.

6) Civic virtue

Bentuk komitmen kepada organisasi secara makro atau keseluruhan seperti menghadiri pertemuan, menyampaikan pendapat atau berpartisipasi aktif dalam kegiatan organisasi.

7) Self development

Bentuk perilaku individu yang sukarela meningkatkan pengetahuan, keterampilan dan kemampuan sendiri seperti mengikuti pelatihan, seminar atau mengikuti perkembangan terbaru dari bidang yang dikuasai.

Organizational Citizenship Behavior ditentukan oleh banyak hal, tidak ada penyebab tunggal dalam perilaku kewargaan organisasi. Sesuatu yang masuk akal bila menerapkan perilaku kewagaan organisasi secara rasional. Salah satu pendekatan motif dalam perilaku organisasi berasal dari kajian McClelland dan rekan-rekannya, yaitu:

1) Motif berprestasi (kebutuhan akan pencapaian)

Motif berprestasi adalah dorongan untuk berprestasi, untuk pencapaian yang berhubungan dengan serangkaian standar.

2) Motif afiliasi (kebutuhan akan afiliasi)

Motif afiliasi adalah keinginan untuk hubungan yang penuh persahabatan dan interpersonal yang dekat.

3) Motif kekuasaan (kebutuhan akan kekuasaaan)

Motif kekuasaan adalah kebutuhan untuk membuat orang lain berperilaku dengan cara yang tidak akan dilakukan tanpa dirinya.

Perilaku kewargaan organisasi merupakan hal yang memiliki dampak positif bagi berjalannya organisasi, yang dapat berkontribusi dalam 
kesuksesan organisasi seperti dengan meningkatkan produktifitas karyawan, meningkatkan stabilitas kinerja organisasi, memperkuat kemampuan organisasi untuk memperoleh dan mendapatkan pegawai terbaik, memungkinkan perusahaan mampu beradaptasi secara efektif dengan perubahan, sehingga $O C B$ dapat dijadikan suatu pembahasan penting untuk diteliti. (P.M. Podsakoff et al., 2000).

Faktor-faktor yang mempengaruhi perilaku kewargaan organisasi yaitu, job satisfaction (Sabahi \& Dashti, 2016) (Ayim \& Haybatollahi, 2015), emotional intelligence (Sabahi \& Dashti, 2016), organizational commitment ( $\mathrm{Ng} \&$ Feldman, 2011) (Jain, 2015) (Shahabinasab et al., 2016) (Devece et al., 2015), leadership (Saeed et al., 2016), job stressors (Pooja et al., 2016), transformational leadership (Srithongrung, 2011) (López-domínguez et al., 2013) (Kim, 2013), employee effectiveness (Srithongrung, 2011), employee engagement (Jenetha Kartika, 2015), perceived organizational support (Chiang \& Hsieh, 2012), psychological empowerment (Chiang \& Hsieh, 2012).

Kecerdasan emosional dapat membantu individu untuk memenuhi tuntutan masyarakat dan memberikan rasa kepuasan diri, hal ini mengintegrasikan kemampuan individu dengan tuntutan sosial dan organisasi. (Dde, Nagar, \& Nadu, 2015). Penelitian di bidang human resource menunjukkan hubungan antara kecerdasan emosional dan variabel lain, bahwa kecerdasan emosional memiliki peran penting dalam pertumbuhan organisasi. (Dde et al., 2015).

Kecerdasan emosional adalah kemampuan untuk mengidentifikasi, mewujudkan perasaan emosi seseorang, dan menerapkannya untuk mengelola hubungan diri sendiri dengan orang lain sehingga membedakan dengan orang lain. Hal ini menunjukkan pentingnya kecerdasan emosional untuk mengelola pekerjaan secara efektif. (Heidarzadeh Hanzaee \& Mirvaisi, 2013). Kecerdasan emosional menggambarkan kemampuan, kapasitas, keterampilan, atau, dalam kasus model kecerdasan emosional sifatnya, kemampuan besar yang dapat dirasakan untuk mengidentifikasi, menilai, mengelola dan mengendalikan emosi diri sendiri, orang lain, dan kelompok. (Ealias \& George, 2012).

Kecerdasan emosional sebagai kombinasi dari faktor-faktor yang memungkinkan seseorang untuk merasa, termotivasi, mengatur suasana hati, kontrol impuls, bertahan dalam menghadapi frustrasi, dan dengan demikian berhasil dalam sehari-hari hidup. (Boyatzis, Goleman, \& Rhee, 2000). Perasaan memahami sendiri, empati untuk perasaan orang lain dan regulasi emosi dengan cara yang meningkatkan hidup. (Gardner, John N. , Jewler, A. Jerome, Barefoot, 2011: 6). Kecerdasan emosional yang didefinisikan sebagai kemampuan individu untuk memantau perasaan, emosi sendiri dan lainnya, untuk membedakan antara mereka, dan menggunakan informasi ini untuk membimbing pikiran dan tindakan seseorang. (Dong, Seo, \& Bartol, 2013). Kesimpulan mengenai pengertian kecerdasan emosional dari para ahli, dapat dikatakan bahwa kemampuan untuk menerima, menilai, atau mengontrol emosi dan orang lain di sekitarnya. Berdasarkan tinjauan ekstensif literatur dapat diidentifikasi ke dalam lima dimensi, diantaranya (Dong et al., 2013):

1) Tanggung jawab baru

Tanggung jawab baru mengacu pada sejauh mana seorang pegawai yang diharapkan dapat mengasumsikan satu set tanggung jawab baru atau yang berbeda. Tanggung jawab baru yang berkembang, membutuhkan pegawai yang dapat menangani rekan kerja baru, bawahan, atau atasan, dalam mengatasi masalah baru.

2) Menciptakan perubahan

Menciptakan perubahan yaitu mencakup tugas-tugas yang menantang seperti menanggapi perubahan yang cepat dan tepat dalam lingkungan serta dapat menerapkan perubahan.

3) Pengalaman kerja perkembangan

Pengalaman kerja perkembangan yaitu tingkat tinggi tanggung jawab dalam hal visibilitas, ruang lingkup dan skala, dan kesulitan (misalnya, membuat keputusansaham yang tinggi).

4) Bekerja melintasi batas-batas

Bekerja melintasi batas-batas merupakan persyaratan kerja untuk bekerja sama dengan orang lain atau rekan kerja atas siapa individu yang memberi perintah yang memiliki kekuasaan formal, seperti rekanrekan, manajer tingkat yang lebih tinggi, dan pemasok eksternal.

5) Mengelola keragaman

Mengelola keragaman, hal ini termasuk orang yang terkemuka dari berbagai budaya, ras, jenis kelamin, atau latar belakang fungsional. Bekerja dengan melintasi batas-batas dan mengelola keragaman perkembangan karena pegawai membutuhkan pengaruh keterampilan yang luar biasa dan kemampuan beradaptasi interpersonal terhadap rekan kerja, bawahan serta atasan.

Goleman menjelaskan bahwa kecerdasan emosi dapat di definisikan dalam lima dimensi yaitu (dalam Miao, Humphrey, \& Qian, 2017):

1) Kesadaran Diri (Self-Awareness)

Kesadan diri (self-awareness) merupakan kemampuan individu secara akurat yang 
dapat memahami diri sendiri dan tetap sadar terhadap emosi diri ketika emosi itu muncul, termasuk tetap mempertahankan cara manusia untuk dapat merespons situasi tertentu dan orang-orang tertentu yang di dalamnya terdapat kesadaran emosi (emotional awareness), penilaian diri yang akurat (accurate self-assessment), dan kepercayaan diri (self confidence).

2) Pengaturan Diri (Self Management)

Kemampuan diri (self management) adalah kemampuan untuk menggunakan kesadaran emosi manusia untuk tetap fleksibel dan secara positif mengarahkan perilaku diri manusia itu sendiri, yang berarti mengelola reaksi emosi manusia itu sendiri kepada semua orang dengan situasi yang memiliki kepekaan terhadap kata hati, untuk digunakan dalam hubungan dan tindakan sehari-hari.

3) Motivasi Diri (Self Motivation)

Motivasi diri (self motivation) merupakan kemampuan yang paling dalam untuk menggerakkan dan menuntun diri menuju sasaran atau tujuan, membantu pengambilan inisiatif serta bertindak sangat efektif, mampu untuk bertahan dan bangkit dari kegagalan atau frustasi. Pemicu timbulnya semangat diri yang meliputi visi, nilai-nilai, tujuan, harapan, hasrat, dan gairah yang menjadi prioritasprioritas dalam diri seseorang.

4) Empati (Emphaty)

Kemampuan manusia untuk secara tepat menangkap emosi orang lain dan mengerti apa yang benar-benar terjadi, dapat diartikan memahami apa yang orang lain pikirkan dan rasakan walaupun tidak merasakan yang sama.

5) Keterampilan Sosial (Relationship Management)

Keterampilan social (relationship management) merupakan kemampuan untuk menggunakan kesadaran emosi manusia dan emosi orang lain untuk mengelola interaksi social yang baik, termasuk berkomunikasi dengan jelas dan efektif untuk mengatasi konflik, yang didalamnya terdapat memajukan individu lain atau orang lain.

Lima domain model EI (Emotional Intellegen) menurut (Goleman et al., 2000) ini telah menjadi standar de facto sejauh menerapkan kecerdasan emosional di tempat kerja yang bersangkutan. Banyak model-berorientasi bisnis mewakili lima domain ini di empat kuadran: dua mewakili kompetensi pribadi dan dua mewakili kompetensi sosial.
1) Kompetensi Personal

Daerah kompetensi personal ini berkaitan dengan tiga dari 'domain' lima Goleman menyebutkan dan membagi menjadi dua kuadran yaitu kesadaran diri dan manajemen diri (Gardner, Jhon N, Jewler, A Jerome, Barefoot O, 2011):

a. Kesadaran diri

Kesadaran diri berarti dapat memahami bagaimana ketepatan untuk menilai keadaan emosi sendiri. Ada tiga komponen untuk kuadran kesadaran diri yaitu, akurat penilaian diri dan kepercayaan diri. Penilaian diri termasuk memahami kekuatan dan kelemahan sendiri. Kekuatan dan kelemahan ini menjadi bersedia untuk mengeksplorasi diri, baik dengan berpikir tentang diri sendiri atau membahas tentang orang lain.

b. Manajemen diri

Manajemen diri dibangun di atas pemahaman yang diperoleh dengan kesadaran diri dan melibatkan pengendalian emosi, sehingga tidak ada pihak lain yang ikut mengontrol. Pengendalian emosi ini bisa disebut juga sebagai kontrol diri, dengan kata lain bagaimana cara mengatur untuk menjaga keseimbangan yang ada di dalam diri dalam menghadapi masalah atau provokasi yang mungkin dihadapi.

2) Kompetensi sosial

Kompetensi sosial merupakan daerah kompetensi yang berkaitan dengan kesadaran sosial dan manajemen hubungan. Keterampilan ini melihat seberapa baik dalam mengelola hubungan dengan orang lain, termasuk mengelola emosi (Gardner, John N. , Jewler, A. Jerome, Barefoot, 2011).

a. Kesadaran sosial

Kesadaran sosial melibatkan dan memperluas kesadaran untuk menyertakan emosi dari orang-orang yang ada di sekitar. Termasuk mampu berempati dengan orang lain dan menyadari bagaimana organisasidi tempat bekerja yang mempengaruhi, hal ini mencakup kemampuan untuk membaca lingkungan dan kekuatan hubungan emosional.

b. Manajemen hubungan

Manajemen hubungan yaitu menggunakan kesadaran emosi sendiri dan orang lain untuk membangun hubungan yang kuat. Mencakup identifikasi, analisis, dan manajemen hubungan dengan orang-orang di dalam dan di luar tim serta melihat 
perkembangan melalui umpan balik dan pembinaan.

Perkembangan manusia sangat dipengaruhi oleh dua faktor, yaitu faktor internal dan eksternal, ada beberapa faktor yang mempengaruhi kecerdasan emosional sebagai berikut. (Goleman et al., 2000):

1) Faktor Otak

Struktur otak manusia terdiri dari batang otak, amigdala, neokorteks. Batang otak merupakan bagian otak untuk mempertahankan hidup. Otak memberikan tempat istimewa bagi amigdala sebagai penjaga emosi, sebagai gudang ingatan emosional, amigdaka berfungsi sebagai tempat penyimpanan semua kenangan baik tentang kejayaan, kegagalan, harapan, ketakutan, kejengkelan, dan frustasi. Neokorteks atau otak piker untuk melakukan penalaran, berfikir secara intelektual dan rasional dalam menghadapi setiap persoalan.

2) Faktor Keluarga

Keluarga merupakan tempat pendidikan pertama dalam mempelajari emosi, dan orang tualah yang sangat berperan. Kehidupan emosional yang dibangun di dalam keluarga sangat berguna bagi anak kelak, bagaimana anak dapat cerdas secara emosional.

3) Faktor Kematangan

Psikis bisa mempengaruhi kercerdasan emosional, keadaan psikis yang didapatkan anak lingkungan keluarga maupun non lingkungan keluarga akan diperkuat dan dipupuk individu dalam diri remaja.

Tujuh unsur utama kemampuan yang sangat penting, berkaitan dengan kecerdasan emosional. (Goleman et al., 2000):

1) Keyakinan

Perasaan kendali dan penguasaan seseorang terhadap tubuh, perilaku, dan dunia, seperti perasaan anak bahwa ia akan berhasil dalam mengerjakan segala sesuatu, tanpa bantuan orang dewasa, hal ini menunjukkan jika memiliki keyakinan yang kuat akan mencapai keberhasilan.

2) Rasa ingin tahu

Perasaan dalam menyelidiki segala sesuatu yang bersifat positif dab menimbulkan kesenangan.

3) Niat

Hasrat dan kemampuan untuk berhasil dan untuk bertindak berdasarkan niat dengan tekun. Ini berkaitan dengan perasaan terampil dan perasaan efektif.

4) Kendali diri

Kemampuan untuk menyesuaikan dan mengendalikan tindakan dengan pola yang sesuai dengan usia, suatu kendali batiniah.

5) Keterkaitan

Kemampuan untuk melibatkan diri dengan orang lain berdasarkan pada perasaan saling memahami.

6) Kecakapan berkomunikasi

Keyakinan dan kemampuan verbal untuk bertukar gagasan, perasaan, dan konsep dengan orang lain dan kenikmatan terlibat dengan orang lain, termasuk orang dewasa.

7) Koperatif

Kemampuan untuk menyeimbangkan kebutuhannya sendiri dengan kebutuhan orang lain dalam kegiatan kelompok.

Kepuasan kerja sebagai respons emosional yang terjadi sebagai akibat interaksi antara nilai pekerja mengenai pekerjaannya dan keuntungan yang diperolehnya dari pekerjaannya, di mana keadaan senang yang diperoleh pegawai dari pekerjaan dan pengalaman. (Swaminathan \& Jawahar, 2013). Kepuasan kerja keseluruhan perasaan atau sikap tentang pekerjaan yang mereka lakukan, yang mengacu pada reaksi afektif utama individu terhadap berbagai aspek pekerjaan dan pengalaman kerja, peningkatan kepuasan kerja sangat penting untuk meningkatkan kinerja dalam pekerjaan. (Shropshire \& Kadlec, 2012). Kepuasan kerja dalam perilaku organisasi termasuk ke dalam level individu pada sikap dan kepuasan kerja.

Kepuasan kerja mengacu pada perasaan seseorang kepuasan pada pekerjaan, yang bertindak sebagai motivasi untuk bekerja. Ini bukan kepuasan diri, kebahagiaan atau kepuasan diri tetapi kepuasan pada kepuasan kerja. (Baghaei \& Tiwary, 2007: 117). Kepuasan kerja adalah menyenangkan atau keadaan emosi positif yang dihasilkan dari suatu penilaian dari seseorang kerja atau pengalaman kerja. (Galletta, Portoghese, Carta, D’Aloja, \& Campagna, 2016). Kepuasan kerja merupakan suatu hal yang sifatnya perseorangan atau individu. Masing-masing individu mempunyai tingkat kepuasan yang berbeda-beda, seperti efektivitas atau respons emosional terhadap berbagai aspek pekerjaan yang dilakukan.

Kepuasan kerja memiliki banyak dimensi. Umumnya mencatat aspek kepuasan dengan pekerjaan itu sendiri, (1) gaji dan pengakuan, (2) hubungan dengan atasan dan rekan kerja, (3) kesempatan untuk kemajuan. (Baghaei \& Tiwary, 2007). 
Setiap dimensi kontribusi untuk perasaan keseluruhan individu kepuasan dengan pekerjaan itu sendiri, tapi orang-orang yang berbeda mendefinisikan "pekerjaan" yang berbeda. Ada tiga dimensi penting untuk kepuasan kerja (Baghaei \& Tiwary, 2007):

1) Kepuasan kerja mengacu pada perasaan seseorang terhadap pekerjaan seseorang, itu hanya dapat disimpulkan tetapi tidak terlihat.

2) Kepuasan kerja sering ditentukan oleh seberapa baik menyebabkan hasil-hasil memenuhi atau melebihi harapan. Kepuasan dalam pekerjaan seseorang berarti komitmen peningkatan dalam pemenuhan persyaratan formal. Ada kemauan besar untuk berinvestasi energi pribadi dan waktu dalam kinerja pekerjaan.

3) Kepuasan hal pekerjaan dan sikap kerja biasanya digunakan secara bergantian. Keduanya merujuk orientasi efektif pada bagian dari individu terhadap peran pekerjaan mereka, yang mereka saat ini menduduki.

Menurut Luthans terdapat lima dimensi yang dapat mempengaruhi kepuasan kerja, yaitu (dalam Thamrin, 2017):

1) Kepuasan terhadap gaji

Gaji berpengaruh signifikan terhadap kepuasan kerja tetapi secara lebih luas juga menggambarkan berbagai dimensi dari kepuasan.

2) Kepuasan terhadap promosi

Kesempatan untuk memperoleh jabatan yang lebih tinggi atau pengembangan karir.

3) Kepuasan terhadap rekan kerja

Rekan kerja memiliki kecakapan secara teknis dan mudan untuk bekerjasama atau mendukung secara social. Rekan kerja yang bersahabat dan kooperatif akan memberikan kepuasan kerja kepada karyawan karena merasa enjoy dalam bekerja.

4) Kepuasan terhadap supervisi atasan Kemampuan atasan dalam memberikan bimbingan teknis pekerjaan dan sikap.

5) Kepuasan terhadap pekerjaan itu sendiri Bagaimana memberikan tugas-tugas yang menarik untuk karyawan, kesempatan untuk belajar, dan kesempatan untuk menrima tanggung jawab.

Christen, Iyer dan Soberman (2006) memberikan model kepuasan kerja, diantaranya (Aziri, 2011):

1) Faktor yang berhubungan dengan pekerjaan

2) Persepsi peran

3) Prestasi kerja
4) Kinerja perusahaan

Faktor yang menyebabkan tingginya tingkat kepuasan kerja pegawai, yaitu (Robbins \& Judge, 2015):

1) Kerja yang menantang secara mental (mentally challenging work)

Pada umumnya pegawai lebih menyukai pekerjaan yang memberi peluang untuk menggunakan keterampilan dan kemampuan yang dimiliki, memberi beragam tugas, memberikan kebebasan dan umpan balik mengenai seberapa baik hasil kerja. Karakteristik ini membuat kerja lebih menantang secara mental.

2) Penghargaan yang sesuai (equitable reward)

Pegawai menginginkan system upah yang adil dan selaras dengan yang diharapkan. Ketika upah yang diberikan dirasa adil, sesuai dengan tuntutan pekerjaan, tingkat individual dan standar upah, hal ini dapat memberikan kepuasan pada pegawai.

3) Kondisi kerja yang mendukung (supportive working condition)

Lingkungan kerja yang nyaman yang nyaman dapat memudahkan pegawai untuk menyelesaikan pekerjaan dengan baik. Penelitian menunjukkan bahwa pegawai menyukai lingkungan fisik yang nyaman, dan fasilitas yang memadai.

4) Kolega yang suportif (supportive colleagues)

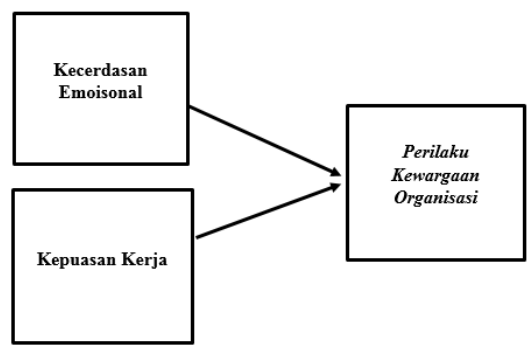

\section{PARADIGMA PENELITIAN}

\section{METODE PENELITIAN}

Penelitian ini dilakukan untuk mengetahui gambaran program promosi jabatan, penghargaan, dan kepuasan kerja. Variabel bebas yang terdapat pada penelitian ini yaitu kecerdasan emosional 1) kesadaran diri (self awarness), 2) pengaturan diri (self management), 3) motivasi diri (self motivation), 4) empati (emphaty), 5) keterampilan sosial (relationship management). Serta variabel kepuasan kerja 1) kepuasan terhadap gaji, 2) kepuasan terhadap promosi, 3) kepuasan terhadap rekan kerja, 4) kepuasan terhadap supervisi atasan, 5) kepuasan terhadap pekerjaan itu sendiri. 
Sedangkan variabel terikat yaitu perilaku kewargaan organisasi 1) altruism, 2) conscientiousenes, 3) sportsmanship, 4) courtesy, 5) civic virtue.

Objek/unit analisis pada penelitian ini adalah pada Badan Kepegawaian Daerah Provinsi Jawa Barat di Bandung. Penelitian ini akan dilakukan pada kurun waktu kurang dari satu tahun di tahun 2018, maka metode penelitian yang digunakan adalah cross sectional method dengan cara mempelajari objek dalam satu kurun waktu tertentu atau tidak berkesinambungan salam jangka waktu panjang. maka metode yang digunakan dalam penelitian ini adalah metode survey explanatory (Malhotra, 2010:96). Metode penelitian yang digunakan dalam penelitian ini adalah penelitian deskriptif. Tujuan dari penelitian deskriptif adalah membuat deskripsi, gambaran atau lukisan secara sistematis, faktual dan akurat, mengatasi fakta-fakta, sifat-sifat, serta hubungan antara fenomena yang diselidiki. Maksud dari penggunaan metode penelitian deskriptif dalam penelitian ini adalah untuk mengetahui gambaran secara keseluruhan mengenai pengaruh program promosi jabatan dan penghargaan terhadap kepuasan kerja karyawan dengan menggunakan distribusi frekuensi.

Teknik yang digunakan dalam penelitian ini adalah teknik Sampel Random Sampling. Peneliti dalam memilih sampel dengan memberikan kesempatan yang sama kepada semua anggota populasi untuk ditetapkan sebagai anggota sampel. Dengan teknik tersebut terpilihnya individu menjadi anggota sampel benar-benar atas dasar faktor kesempatan (chance), dalam arti memiliki kesempatan yang sama, bukan karena adanya pertimbangan subjektif dari peneliti. Selanjutnya populasi karyawan sebanyak 138 pegawai, dengan pengambilan jumlah sampel menggunakan rumus Slovin Sugiyono, (2013:11) menjadi 103 pegawai. Sumber data penelitian adalah sumber data yang diperlukan untuk penelitian baik yang diperoleh secara langsung kepada pengumpul data. Diantaranya:

1. Data primer yaitu data yang dibuat oleh peneliti untuk maksud khusus menyelesaikan permasalahan yang sedang ditangani. Dalam penelitian ini yang menjadi sumber data adalah kuesioner yang disebarkan kepada unit sampel data penelitian.

2. Data sekunder yaitu data yang telah dikumpulkan untuk maksud selain untuk menyelsaikan masalah yang sedang dihadapi. Dalam penelitian ini yang menjadi sumber data sekunder adalah dokumentasi objek penelitian, literatur, artikel, jurnal serta studi internet yang berkenaan dengan penelitian yang dilakukan.

HASIL PENELITIAN DAN PEMBAHASAN

Gambaran Kecerdasan Emosional
TABEL 1.1

REKAPITULASI PEGAWAI BADAN KEPEGAWAIAN DAERAH PROVINSI JAWA BARAT TERHADAP VARIABEL KECERDASAN EMOSIONAL

\begin{tabular}{|c|c|c|c|c|c|}
\hline No & Dimensi & Skor & $\begin{array}{l}\text { Skor } \\
\text { Rata- } \\
\text { rata }\end{array}$ & $\begin{array}{l}\text { Skor } \\
\text { Ideal }\end{array}$ & $\%$ \\
\hline 1 & $\begin{array}{l}\text { Kesadaran Diri } \\
\text { (Self Awarness) }\end{array}$ & 1734 & 578 & 2163 & 80.2 \\
\hline 2 & $\begin{array}{l}\text { Pengaturan Diri } \\
\text { (Self } \\
\text { Management) }\end{array}$ & 1755 & 585 & 2163 & 81.1 \\
\hline 3 & $\begin{array}{l}\text { Motivasi Diri } \\
\text { (Self } \\
\text { Motivation) }\end{array}$ & 1749 & 583 & 2163 & 80.9 \\
\hline 4 & $\begin{array}{l}\text { Empati } \\
\text { (Emphaty) }\end{array}$ & 1774 & 591.3 & 2163 & 82.0 \\
\hline
\end{tabular}

\begin{tabular}{clcccc}
4 & 1774 & 591.3 & 2163 & 82.0 \\
\hline 5 & $\begin{array}{l}\text { Keterampilan } \\
\text { Sosial } \\
\text { (Relationship } \\
\text { Management) }\end{array}$ & 2432 & 608 & 2884 & 84.3 \\
& $\begin{array}{l}\text { Total Skor } \\
\text { Tanggapan }\end{array}$ & 9444 & 2943,3 & 11.536 & 81,7 \\
\hline
\end{tabular}

Kecerdasan Emosional berdasarkan item pernyataan (indikator) menunjukkan bahwa nilai tertinggi pada dimensi keterampilan sosial (relationship management) 2432 atau 84,3\%, empati (emphaty) memperoleh skor sebesar 1774 atau sebesar $82,0 \%$, dimensi pengaturan diri (self management) memperoleh skor sebesar 1755 atau $81,1 \%$, dimensi motivasi diri (self motivation) memperoleh skor sebesar 1749 atau 80,9\%, dimensi kesadaran diri (self awareness) memperoleh skor sebesar 1734 atau 80,2\%, dengan indikator mengenali emosi diri, mengenali kemampuan diri, mengelola emosi, mengatur emosi, memotivasi diri sendiri, kreativitas diri sendiri, memahami orang lain, mengenali emosi orang lain. Secara keseluruhan variabel kecerdasan emosional memperoleh skor 9444, apabila skor ideal dihitung menjadi persen maka diperoleh sebesar $81,7 \%$, hal ini menunjukkan terlaksananya kecerdasan emosional di Badan Kepegawaian Daerah Provinsi Jawa Barat, dalam kategori baik namun hal tersebut perlu ditingkatkan kembali untuk dapat kategori sangat baik. Dalam penelitian ini dapat diketahui kedudukan variable kecerdasan emosional berdasarkan rekapitulasi skor dari keseluruhan dimensi. Nilai-nilai tersebut dibandingkan dengan kriteria skor standar, yang didapat melalui perhitungan skor ideal (criterium) dan skor terkecil. Melalui skor standar tersebut dapat diketahui daerah kontinum yang menunjukkan wilayah ideal dari variabel Kecerdasan Emosional.

Perolehan skor yang didasarkan pada hasil pengolahan data dari responden pada variabel 
kecerdasan emosional adalah 9444, skor tersebut secara kontinum dapat digambarkan sebagai berikut:

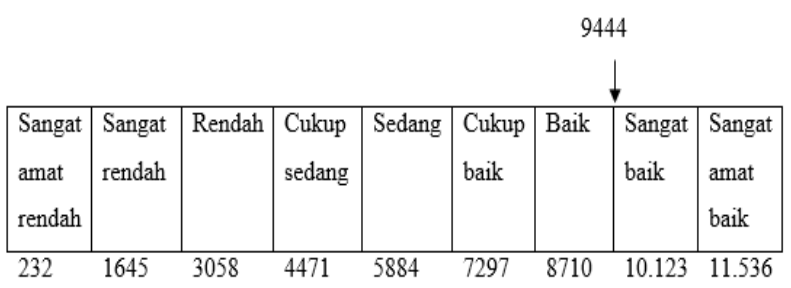

GAMBAR 1.2

GARIS KONTINUM VARIABEL

KECERDASAN EMOSIONAL $\left(\mathrm{X}_{1}\right)$

Skor nilai pada Kecerdasan Emosional di Badan Kepegawaian Daerah Provinsi Jawa Barat di Bandung dengan data penelitian yaitu termasuk dalam kategori tinggi. Hal ini menunjukkan penerapan kesadaran diri (self awareness), pengaturan diri (self management), motivasi diri (self motivation), empati (emphaty), keterampilan social (relationship management) pada kecerdasan emosional dikatakan tinggi akan tetapi masih perlu ditingkatkan kembali. Kecerdasan emosional adalah kemampuan untuk mengidentifikasi perasaan emosi seseorang, serta mengelola hubungan dengan orang lain. Hal ini menunjukkan pentingnya kecerdasan emosional untuk mengelola pekerjaan secara efektif. (Heidarzadeh Hanzaee \& Mirvaisi, 2013).

TABEL 1.2

REKAPITULASI PEGAWAI BADAN KEPEGAWAIAN DAERAH PROVINSI JAWA BARAT TERHADAP VARIABEL KEPUASAN KERJA

\begin{tabular}{|c|c|c|c|c|c|}
\hline \multicolumn{6}{|c|}{ Kepuasan Kerja } \\
\hline No & Dimensi & Skor & $\begin{array}{l}\text { Skor } \\
\text { Rata- } \\
\text { rata }\end{array}$ & Skor Ideal & $\%$ \\
\hline 1 & $\begin{array}{l}\text { Kepuasan } \\
\text { terhadap gaji }\end{array}$ & 2437 & 487 & 3605 & 67.6 \\
\hline 2 & $\begin{array}{l}\text { Kepuasan } \\
\text { terhadap } \\
\text { promosi }\end{array}$ & 2543 & 636 & 2884 & 88.2 \\
\hline 3 & $\begin{array}{l}\text { Kepuasan } \\
\text { terhadap } \\
\text { supervisi } \\
\text { atasan }\end{array}$ & 3082 & 616 & 3605 & 85.5 \\
\hline 4 & $\begin{array}{l}\text { Kepuasan } \\
\text { terhadap } \\
\text { rekan kerja }\end{array}$ & 2390 & 598 & 2884 & 82.9 \\
\hline 5 & $\begin{array}{l}\text { Kepuasan } \\
\text { terhadap } \\
\text { pekerjaan itu } \\
\text { sendiri }\end{array}$ & 1746 & 582 & 2163 & 80.7 \\
\hline & $\begin{array}{l}\text { Total Skor } \\
\text { Tanggapan }\end{array}$ & 12198 & 2919 & 15.141 & 81.0 \\
\hline
\end{tabular}

Besarnya skor yang dimiliki setiap dimensi dari kepuasan kerja dapat menjelaskan bahwa adanya kepuasan kerja pada pegawai Badan Kepegawaian Daerah Provinsi Jawa Barat di Bandung berpengaruh besar terhadap Perilaku Kewargaan Organisasi.

Kepuasan Kerja berdasarkan item pernyataan (indikator) menunjukkan bahwa nilai tertinggi pada dimensi kepuasan terhadap promosi memperoleh skor sebesar 2543 atau 88,2\%, dimensi kepuasan terhadap rekan kerja memperoleh skor sebesar 3082 atau $85,5 \%$, dimensi kepuasan terhadap supervisi atasan memperoleh skor sebesar 2390 atau 82,9\%, dimensi kepuasan terhadap pekerjaan itu sendiri sebesar 1746 atau 80,7\%. Hal ini menunjukkan bahwa terlaksananya kepuasan kerja di Badan Kepegawaian Daerah Provinsi Jawa Barat. Sedangkan untuk dimensi dengan nilai terendah yaitu dimensi kepuasan terhadap gaji memperoleh skor sebesar 2437 atau 67,6\%, hal ini menunjukkan bahwa pegawai cenderung kurang puas terhadap gaji yang diterima. Secara keseluruhan variabel kepuasan kerja memperoleh skor 12198, apabila di presentasikan ke dalam skor ideal maka diperoleh presentase sebesar $81,0 \%$, hal ini menunjukkan bahwa terlaksananya kepuasan kerja di Badan Kepegawaian Daerah Provinsi Jawa Barat.

Dalam penelitian ini dapat diketahui kedudukan variabel kepuasan kerja berdasarkan rekapitulasi skor dari keseluruhan dimensi. Nilainilai tersebut dibandingkan dengan kriteria skor standar, yang didapat melalui perhitungan skor ideal (criterium) dan skor terkecil. Melalui skor standar tersebut dapat diketahui daerah kontinum yang menunjukkan wilayah ideal dari variabel kepuasan kerja.

Perolehan skor yang didasarkan pada hasil pengolahan data dari responden pada variabel kepuasan kerja adalah 12.198, skor tersebut secara kontinum dapat digambarkan sebagai berikut:

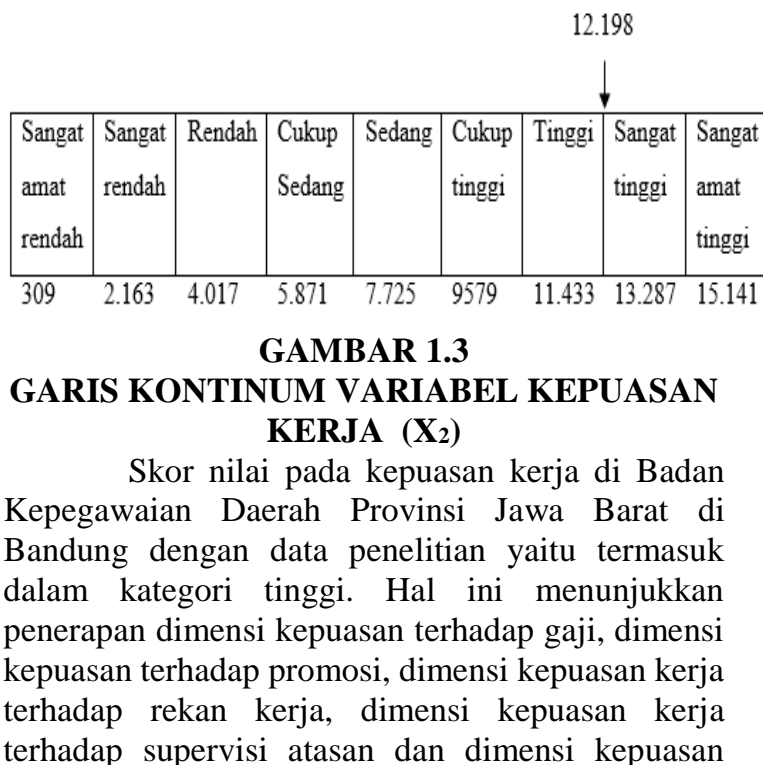


kerja terhadap pekerjaan itu sendiri pada kepuasan kerja dikatakan tinggi akan tetapi masih perlu ditingkatkan kembali untuk mencapai kategori sangat tinggi. Kepuasan kerja mengacu pada seseorang tentang perasaan kepuasan pada pekerjaan yang bertindak sebagai motivasi untuk bekerja, ini bukan kepuasan diri atau kebahagiaan yang diciptakan diri sendiri tetapi kepuasan pada pekerjaan. Luthans (dalam Thamrin, 2017).

Gambaran Perilaku Kewargaan Organisasi

\section{TABEL 1.3}

REKAPITULASI PEGAWAI BADAN KEPEGAWAIAN DAERAH PROVINSI JAWA BARAT TERHADAP VARIABEL PERILAKU KEWARGAAN ORGANISASI

Perilaku Kewargaan Organisasi

\begin{tabular}{|c|c|c|c|c|}
\hline No & Dimensi & Skor & $\begin{array}{c}\text { Skor } \\
\text { Rata- } \\
\text { rata } \\
\end{array}$ & Skor Ide \\
\hline 1 & Alturism & 1135 & 568 & 1442 \\
\hline 2 & $\begin{array}{l}\text { Conscientiousse } \\
\text { nes }\end{array}$ & 2299 & 575 & 2884 \\
\hline 3 & Sportmanship & 2369 & 592 & 2884 \\
\hline 4 & Courtesy & 3041 & 760 & 3605 \\
\hline 5 & Civic Virtue & 3009 & 602 & 3605 \\
\hline Skor & Total Tanggapan & 11853 & 3097 & 14.420 \\
\hline & $\begin{array}{l}\text { Besarnya sk } \\
\text { ri perilaku ke } \\
\text { enjelaskan bahwa } \\
\text { ganisasi pada p } \\
\text { derah Provinsi Jaw } \\
\text { Perilaku ke } \\
\text { m pernyataan (in } \\
\text { lai tertinggi pada } \\
\text { or sebesar } 760 \text { ata } \\
\text { emperoleh skor se } \\
\text { ortmanship memp } \\
1 \% \text {, Conscientiou } \\
5 \text { atau } 79,7 \% \text {. } \\
\text { laksananya perila } \\
\text { dan Kepegawaian } \\
\text { dangkan untuk d } \\
\text { itu alturism memp } \\
7 \% \text {. }\end{array}$ & $\begin{array}{l}\text { yang dim } \\
\text { rgaan } \\
\text { danya p } \\
\text { wai Ba } \\
\text { arat di B } \\
\text { gaan org } \\
\text { ator) me } \\
\text { ensi Cor } \\
4,4 \% \text {, di } \\
\text { ar } 602 \text { at } \\
\text { leh skor } \\
\text { es memp } \\
\text { ini me } \\
\text { kewarg } \\
\text { aerah Pr } \\
\text { nsi den } \\
\text { leh skor }\end{array}$ & $\begin{array}{l}\text { iki setia } \\
\text { rganisas } \\
\text { ilaku k } \\
\text { an Kep } \\
\text { ndung. } \\
\text { hisasi be } \\
\text { unjukk. } \\
\text { itesy me } \\
\text { hensi Ci } \\
\text { u 83,5\% } \\
\text { sebesar } \\
\text { roleh sk } \\
\text { unjukka } \\
\text { an orga } \\
\text { vinsi Ja } \\
\text { an nilai } \\
\text { sebesar }\end{array}$ & $\begin{array}{r}\text { dimensi } \\
\text { dapat } \\
\text { wargaan } \\
\text { gawaian } \\
\text { dasarkan } \\
\text { bahwa } \\
\text { nperoleh } \\
\text { ic Virtue } \\
\text { dimensi } \\
592 \text { atau } \\
\text { r sebesar } \\
\text { bahwa } \\
\text { isasi di } \\
\text { a Barat. } \\
\text { terendah } \\
135 \text { atau }\end{array}$ \\
\hline
\end{tabular}

Hal ini menunjukkan pegawai bersedia membantu atau menggantikan posisi rekan kerjanya yang mengalami kesulitan. Secara keseluruhan variabel perilaku kewargaan organisasi memperoleh skor 11853, apabila dihitung persen dari skor ideal maka diperoleh sebesar $85,9 \%$, hal ini menunjukkan bahwa terlaksananya kepuasan kerja di Badan Kepegawaian Daerah Provinsi Jawa Barat di Bandung, namun hal tersebut perlu ditingkatkan kembali untuk mencapai kategori sangat baik.

Dalam penelitian ini dapat diketahui kedudukan variable perilaku kewargaan organisasi berdasarkan rekapitulasi skor dari keseluruhan dimensi. Nilai-nilai tersebut dibandingkan dengan kriteria skor standar, yang didapat melalui perhitungan skor ideal (criterium) dan skor terkecil. Melalui skor standar tersebut dapat diketahui daerah kontinum yang menunjukkan wilayah ideal dari variabel perilaku kewargaan organisasi.

\subsection{3}

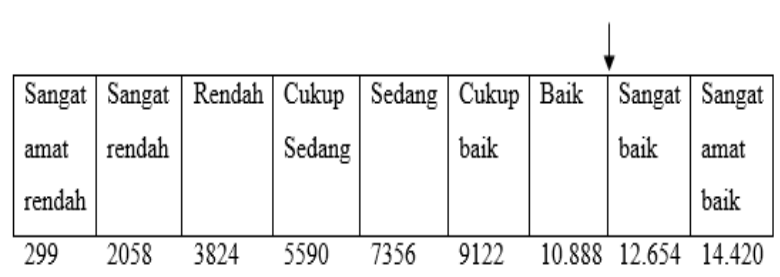

GAMBAR 1.4

$\%$

GARIS KONTINUM VARIABEL PERILAKU KEWARGAAN ORGANISASI (Y)

Skor nilai pada Kecerdasan Emosional di 78.Badan Kepegawaian Daerah Provinsi Jawa Barat di Bandung dengan data penelitian yaitu termasuk 79. dalam kategori tinggi. Hal ini menunjukkan 82.penerapan alturism, conscientiousenes, sportmanship, countesy dan civic virtue pada 84. perilaku kewargaan organisasi di Badan 83. Kepegawaian Daerah Provinsi Jawa Barat di 85.9Bandung dapat dikatakan tinggi akan tetapi masih perlu ditingkatkan kembali. Perilaku kewargaan organisasi mengacu meningkatkan efektivitas di dalam organisasi, dapat mewujudkan kesejahteraan orang lain dengan sukarela membantu rekan kerja dalam menyelesaikan tugas. (McShane \& Glinow, 2010).

\section{KESIMPULAN DAN REKOMENDASI}

Berdasarkan hasil penelitian yang telah dilakukan menggunakan analisis deskriptif dengan distribusi frekuensi dapat diambil kesimpulan yaitu, hasil penelitian menyatakan bahwa kecerdasan emosional berada dalam kategori baik, dimensi keterampilan sosial (relationship management) merupakan dimensi yang memiliki penilaian yang paling tinggi, sementara dimensi yang memiliki penilaian paling rendah yaitu kesadaran diri (self awarness).

Serta kepuasan kerja berada dalam kategori tinggi, dimensi kepuasan terhadap promosi jabatan merupakan dimensi yang memiliki penilaian yang paling tinggi, sementara dimensi yang memiliki penilaian paling rendah adalah kepuasan terhadap gaji. Dan perilaku kewargaan organisasi dalam kategori baik, dimensi courtesy merupakan dimensi yang memiliki penilaian paling tinggi, sementara dimensi yang memperoleh skor terendah terdapat pada alturism.

Adanya penelitian ini diharapkan dapat membantu peneliti berikutnya dalam melakukan penelitian mengenai kecerdasan emosional, 
kepuasan kerja dan perilaku kewargaan organisasi dengan menggunkan indikator yang berbeda dari sumber teori yang lebih beragam, dan terhadap objek yang berbeda, karena banyak keterbatasan dalam penelitian ini, khususnya yang berkaitan dengan metode penelitian dan teknik pengumpulan data.

Dapat dikatakan bahwa dalam penelitian ini sistem perilaku kewargaan organisasi yang dimiliki oleh Badan Kepegawaian Daerah Provinsi Jawa Barat di Bandung telah diaplikasikan dengan baik, namun perilaku kewargaan organisasi perlu ditingkatkan lagi. Adapun saran-saran sebagai masukan untuk perbaikan kepuasan kerja sebagai berikut:

1. Hasil penelitian menyatakan bahwa kecerdasan emosional berpengaruh terhadap perilaku kewargaan organisasi, maka penulis merekomendasikan kepada organisasi dan pimpinan untuk meningkatkan kecerdasan emosional pegawai dengan mengadakan kegiatan dan pelatihan maupun seminar yang dapat mempengaruhi pegawai untuk bersikap seperti mendengarkan orang lain dengan pikiran terbuka, menerima apa yang dikatakan orang lain, mengurangi stress dengan rekreasi bersama, berkomunikasi dengan baik antar pegawai, rekan kerja, dan pimpinan dan percaya terhadap kemampuan diri. Sehingga pegawai mampu menjadi warga organisasi yang baik.

2. Hasil penelitian menyatakan bahwa kepuasan kerja berpengaruh terhadap perilaku kewargaan organisasi, maka penulis merekomendasikan kepada organisasi dan pemimpin untuk memperhatikan kepuasan pegawai dalam pemberian gaji, serta memberikan tunjangan kepada para pegawai, hal tersebut bertujuan untuk meningkatkan rasa puas yang berimbas pada peningkatan kualitas dalam bekerja. Pemberian tunjangan dan gaji yang sesuai dapat membantu pegawai dalam memberikan hasil yang baik dari tugas mereka, sehingga pegawai mampu menjadi warga organisasi yang baik.

3. Hasil penelitian ini menyatakan bahwa kecerdasan emosional dan kepuasan kerja berpengaruh pada perilaku kewargaan organisasi. Dengan demikian penulis merekomendasikan kepada organisasi dan pemimpin untuk terus meningkatkan kecerdasan emosional pegawai dan meningkatkan kepuasan kerja pegawai, agar perilaku kewargaan organisasi dapat meningkat sehingga kulitas kerja di organisasi BKD semakin baik. Faktor yang mempengaruhi perilaku kewargaan organisasi yaitu kecerdasan emosional dan kepuasan kerja. Peningkatan kecerdasan emosional pegawai perlu ditingkatkan lagi terutama dalam memberikan dorongan agar pegawai percaya diri, dapat mengontrol emosi diri dan menghindari stress. Kepuasan kerja pun perlu ditingkatkan lagi dalam memberikan gaji yang sesuai untuk pegawai, pemberian tunjangan dan promosi jabatan yang adil pada setiap pegawai, semua itu demi kemajuan organisasi menjadi lebih baik.

\section{DAFTAR PUSTAKA}

Ali, M. (2013). Penelitian Kependidikan Prosedur \& Strategi. Bandung: CV Angkasa

Arikunto. (2010). Prosedur Penelitian: Suatu Pendekatan Praktik (Edisi Revisi). Jakarta: Rineka Cipta.

Asep Hermawan. Penelitian Bisnis Paradigma Kuantitatif. Jakarta: PT. Grasindo

Ealias, A., \& George, J. (2012). Emotional Intelligence and Job Satisfaction: A Correlational study. Commerce and Behavioural Science, 1(4), 37-42.

Gaddis, A. K. (2016). Teacher Organizational Citizenship Behavior and Principal Emotional Intelligence : How They Relate and Interact.

Gardner, Jhon N, Jewler, A Jerome, Barefoot O. (2011). Understanding Emotional Intelligence. Your College Experience Strategies for Success.

Gujarati, N. . (2003). Basic Econometrics (4th ed). New York: McGraw-Hill Companies, Inc.

Goleman, D. (2005). Goleman 2005. Jakarta.

Harris, O. J., \& Hartman, S. J. (2002). Organizational Behavior. https://doi.org/10.1146/annurev.ps.46.020195 .000423

Herjanto, E. (2015). Manajemen Operasi (Ketiga). Jakarta: Grafindo.

Kuntjojo. (2009). Metodologi Penelitian. Kediri: Universitas Nusantara PGRI Kediri.

Luthans, F. (2006). Perilaku Organisasi. Edisi 10. Yogyakarta: Andi.

Mathur, G. (2016). A Systematic Guide from Research.

McShane \& Glinow, V. (2010). Organizational Behavior.

Podsakoff, P. M., Mackenzie, S. B., Paine, J. B., \& Bachrach, D. G. (2000). Organizational citizenship behaviors: A critical review of the theoretical and future research, 26(3), 513- 
563.

Riduwan, \& Kuncoro, E. A. (2012). Belajar Mudah Penelitian untuk Guru-Karyawan dan Peneliti Pemula. Bandung: Alfabeta.

Robbins, S.P.\& Judge, T.A. (2015).Perilaku Organisasi. (R. Saraswati \& F. Sirait, Eds.) (Edisi Enam). Jakarta: Salemba Empat.

Sandjojo. (2014). Metode Analisis Jalur. Jakarta: Alfabeta.

Sekaran. (2014). Research Methods for Business (Terjemahan). Jakarta: Salemba Empat.

Sugiyono, A. (2009). Manajemen Keuangan untuk Praktisi Keuangan. Jakarta: Grasindo.

Sugiyono, (2013). Metode Penelitian Pendidikan (Pendekatan Kuantitatif, dan R\&D). Bandung: Alfabeta.Kualitatif, dan $R \& D)$. Bandung: Alfabeta.

Sugiyono. (2014a). Metode Penelitian Kuantitatif Kualitatif dan $R \& D$. Bandung: Alfabeta.

Zainal, V. R., Hadad, M. D., \& Ramly, M. (2014). Kepemimpinan dan Perilaku Organisasi. Depok: PT. RajaGrafindo Persada.

\section{Jurnal}

Arikunto. (2010). Metodologi Penelitian.

Ayim, G. S., \& Haybatollahi, M. (2015). Organizational citizenship behaviour An empirical investigation of the impact of age and job satisfaction on Ghanaian industrial workers.

Aziri, B. (2011). Job Satisfaction: a Literature Review. Management Research and Practice (Vol. 3).

Baghaei, R., \& Tiwary, S. N. (2007). A comparative study of human resource management practices in private and public hospitals of Iran with special reference to job satisfaction of nurses. Retrieved from http://shodhganga.inflibnet.ac.in/browse?type $=$ author\&order $=$ ASC \&rpp $=20 \&$ value $=$ Bagha ei,+Rahim

Bolino, M. C., Harvey, J., \& Lepine, J. A. (2015). “ Well , I ' $m$ Tired of Tryin '!” Organizational Citizenship Behavior and Citizenship Fatigue, 100(1), 56-74.

Boyatzis, R., Goleman, D., \& Rhee, K. (2000). Clustering competence in emotional intelligence: Insights from the Emotional Competence Inventory (ECI). Handbook of Emotional Intelligence. Retrieved from http://www.eiconsortium.org/pdf/eci_acticle. pdf

Brightman, B. K., Moran, J. W., Brightman, B. K., \& Moran, J. W. (2011). Building organizational citizenship.
Bruck, C. S., Allen, T. D., \& Spector, P. E. (2002). The relation between work-family conflict and job satisfaction: A finer-grained analysis. Journal of Vocational Behavior, 60(3), 336353. https://doi.org/10.1006/jvbe.2001.1836

Chiang, C., \& Hsieh, T. (2012). International Journal of Hospitality Management The impacts of perceived organizational support and psychological empowerment on job performance: The mediating effects of organizational citizenship behavior. International Journal of Hospitality Management, $\quad 31(1), \quad$ 180-190. https://doi.org/10.1016/j.ijhm.2011.04.011

Dde, M. W., Nagar, A., \& Nadu, T. (2015). Management Influence of Emotional Intelligence on OCB of it Executives Karthikeyan , S Arulkumar, S ABSTRACT Research Scholar, Bharathiar University, Coimbatore, Tamil Nadu . KEYWORDS : Emotional Intelligence ( EI ), Organizational Citizenship Behavio, (7), 171-173.

Devece, C., Palacios-marqués, D., \& Pilar, M. (2015). Organizational commitment and its effects on organizational citizenship behavior in a high-unemployment environment is. Journal of Business Research. https://doi.org/10.1016/j.jbusres.2015.10.069

Dhitiporn Chompookum, C. B. D. (2006). The effects of internal career orientations on organizational citizenship behavior in Thailand. https://doi.org/10.1108/13620430410544355

Dong, Y., Seo, M.-G., \& Bartol, K. M. (2013). Affect-based Model of Developmental Job Experience No Pain, No Gain: An Affectbased Model of Developmental Job Experience and the Buffering Effects of Emotional Intelligence Department of Management University of Connecticut School of Business Myeong-G. Academy of Management Journal, published(2011.0687), 1-53. https://doi.org/10.5465/amj.2011.0687

Ealias, A., \& George, J. (2012). Emotional Intelligence and Job Satisfaction: A Correlational study. Commerce and Behavioural Science, 1(4), 37-42.

Ebrahimpour, H., Zahed, A., Khaleghkhah, A., \& Bager, M. (2011). Procedia Social and A survey relation between organizational culture and organizational citizenship behavior, 0 , 1920-1925.

https://doi.org/10.1016/j.sbspro.2011.10.373 
Ebrahimpour, H., Zahed, A., Khaleghkhah, A., \& Sepehri, M. B. (2011). A survey relation between organizational culture and organizational citizenship behavior. Procedia - Social and Behavioral Sciences, 30, 19201925.

https://doi.org/10.1016/j.sbspro.2011.10.373

Eyvind Elstad, Knut-Andreas Christophersen, A. T. (2012). The strength of accountability and teachers, organisational citizenship behaviour.

https://doi.org/10.1108/09578231211249844

Gaddis, A. K. (2016). Teacher Organizational Citizenship Behavior and Principal Emotional Intelligence : How They Relate and Interact.

Galletta, M., Portoghese, I., Carta, M. G., D’Aloja, E., \& Campagna, M. (2016). The Effect of Nurse-Physician Collaboration on Job Satisfaction, Team Commitment, and Turnover Intention in Nurses. Research in Nursing and Health, 39(5), 375-385. https://doi.org/10.1002/nur.21733

Gardner, John N. , Jewler, A. Jerome, Barefoot, B. O. (2011). Understanding Emotional Intelligence. Your College Experience Strategies for Success.

Goleman, D. (2005). Goleman 2005.pdf. Jakarta.

Handsome, J. D. (2010). The relationship between leadership style and job satisfaction. Dissertation Abstracts International Section A: Humanities and Social Sciences, 70(12-A), 4758. Retrieved from http://gateway.proquest.com/openurl?url_ver $=\mathrm{Z39} .88$ -

2004\&rft_val_fmt=info:ofi/fmt:kev:mtx:diss ertation\&res_dat=xri:pqdiss\&rft_dat=xri:pqd iss:3379818\%5Cnhttp://ovidsp.ovid.com/ovi dweb.cgi? $=$ JS $\&$ PAGE $=$ reference $\& D=$ psyc 6 $\& N E W S=N \& A N=2010-99110-455$

Harris, O. J., \& Hartman, S. J. (2002). Organizational Behavior. https://doi.org/10.1146/annurev.ps.46.020195 .000423

Heidarzadeh Hanzaee, K., \& Mirvaisi, M. (2013). A survey on impact of emotional intelligence, organizational citizenship behaviors and job satisfaction on employees' performance in Iranian hotel industry. Management Science Letters, 3(5), 1395-1402. https://doi.org/10.5267/j.ms1.2013.04.010

Hellriegel, D., \& Slocum, J. W. (2011). Organizational Behavior.

Jain, A. K. (2015). Volunteerism and organisational culture Relationship to organizational commitment. https://doi.org/10.1108/CCM11-2013-0167

Jenetha Kartika, E. S. M. (2015). ANALISIS FAKTOR-FAKTOR YANG MEMPENGARUHI ORGANIZATIONAL CITIZENSHIP BEHAVIOR, 14(2), 245-270.

Judge, T. a., \& Klinger, R. (2008). Job Satisfaction: Subjective Well-Being at Work. The Science of Subjective Well-Being. https://doi.org/10.1111/j.1475682X.2000.tb00904.x

Kim, H. (2013). Transformational Leadership , Organizational Clan Culture , Organizational Affective Commitment, and Organizational Citizenship Behavior: A Case of South Korea $\hat{a}^{\mathrm{TM}} \quad \mathrm{S} \quad$ Public $\quad$ Sector. https://doi.org/10.1007/s11115-013-0225-z

Korkmaz, T., \& Arpacı, E. (2009). Relationship of organizational citizenship behavior with emotional intelligence. Procedia - Social and Behavioral Sciences, 1(1), 2432-2435. https://doi.org/10.1016/j.sbspro.2009.01.428

Kuntjojo. (2009). Metodologi Penelitian.

López-domínguez, M., Enache, M., Sallan, J. M., \& Simo, P. (2013). Transformational leadership as an antecedent of change-oriented organizational citizenship behavior is. Journal of Business Research. https://doi.org/10.1016/j.jbusres.2013.02.041

Luthans, F. (2006). Perilaku Organisasi. (ANDI, Ed.). Yogyakarta.

Luthans, F. (2012). Personality, Perception, and Employee Attitudes. Organizational Behavior: An edivence-Based Approach.

Masharyono. (2015). Pengaruh Job Characteristics terhadap Semangat Kerja Pegawai (Survey pada Pegawai PNS di Lingkungan Disparbud Jabar), 3(3), 813-830.

Masharyono, Sumiyati, Toyib. (2016). Physical Work Environment Effect on Employee Productivity of Textile Industry, 15, 630-632.

Masharyono \& Syamsul Hadi Senen. (2015). Analisis Job Performance Pegawai Honorer Administrasi Dengan Kompetensi Dan Job Characteristics Dalam Mendukung Universitas Pendidikan Indonesia Mencapai Leading and Outstanding, 10 No.2, 120-137.

Mathur, G. (2016). A Systematic Guide from Research.

McShane \& Glinow, V. (2010). Organizational 
Behavior.

Miao, C., Humphrey, R. H., \& Qian, S. (2017). Are the emotionally intelligent good citizens or counterproductive? A meta-analysis of emotional intelligence and its relationships with organizational citizenship behavior and counterproductive work behavior. Personality and Individual Differences, 116, 144-156. https://doi.org/10.1016/j.paid.2017.04.015

Mshellia, P. S., Malachy, O. D. Y., Sabo, B., \& AbuAbdissamad, A. M. (2016). Emotional intelligence and contextual performance among nursing professionals in jos metropolis, plateau state, Nigeria. Journal of Good Governance and Sustainable Development in Africa (JGGSDA), 3(1), 1933.

Ng, T. W. H., \& Feldman, D. C. (2011). Affective organizational commitment and citizenship behavior: Linear and non-linear moderating effects of organizational tenure. Journal of Vocational Behavior, 79(2), 528-537. https://doi.org/10.1016/j.jvb.2011.03.006

Organ, D. W., Konovsky, M., \& Freeman, A. B. (1989). Cognitive Versus Affective Determinants of Organizational Citizenship Behavior. Journal of Applied Psychology, 74(I), 157-164. https://doi.org/10.1037/00219010.74.1.157

Organ, D. W., \& Ryan, K. (1995). A METAANALTTIC REVIEW OF ATTITUDINAL AND DISPOSITIONAL PREDICTORS OF ORGANIZATIONAL CITIZENSHIP BEHAVIOR.

Ouyang, Z., Sang, J., Li, P., \& Peng, J. (2015). Organizational justice and job insecurity as mediators of the effect of emotional intelligence on job satisfaction: A study from China. Personality and Individual Differences, 76, 147-152. https://doi.org/10.1016/j.paid.2014.12.004

Podsakoff, P. M., Mackenzie, S. B., Paine, J. B., \& Bachrach, D. G. (2000). Organizational Citizenship Behaviors : A. https://doi.org/10.1177/01492063000260030 7

Podsakoff, P. M., Mackenzie, S. B., Paine, J. B., \& Bachrach, D. G. (2000). Organizational citizenship behaviors: A critical review of the theoretical and future research, 26(3), 513563.

Pooja, A. A., Clercq, D. De, \& Belausteguigoitia, I. (2016). Job Stressors and Organizational
Citizenship Behavior: The Roles of Organizational Commitment and Social Interaction. https://doi.org/10.1002/hrdq

Pratama, K. F., \& Purnama, R. (2016). The Effect of Social Work Environment on Employee Productivity in Manufacturing Company in Indonesia, 15, 574-575.

Putri Rahmawati, Sumiyati, \& Masharyono. (2016). LEADER MEMBER EXCHANGE DAN KEPRIBADIAN UNTUK MENINGKATKAN EMPLOYEE VOICE KOPONTREN DT, 11, 38-44.

Robbins \& Judge. (2015). ORGANIZATIONAL BEHAVIOR.

Romle, A. R., Faezah, N., Talib, M., Sabrina, N., \& Shahuri, S. (2016). The relationship between organizational citizenship behavior and high performance organization from the perspective of the students in the higher education institution in, 3(5), 37-42.

Sabahi, A. H., \& Dashti, N. S. (2016). Management Science Letters, 6, 475-480. https://doi.org/10.5267/j.msl.2016.6.001

Sabahi, A. H., \& Sanai Dashti, N. (2016). The effect of emotional intelligence and job satisfaction on organizational citizenship behavior. Management Science Letters, 6, 475-480. https://doi.org/10.5267/j.msl.2016.6.001

Saeed, M., Zaman, K., \& Hossan, C. (2016). Authentic leadership, work engagement and organizational citizenship behaviors in petroleum company.

Saleem, H. (2015). The Impact of Leadership Styles on Job Satisfaction and Mediating Role of Perceived Organizational Politics. Procedia Social and Behavioral Sciences, 172, 563569.

https://doi.org/10.1016/j.sbspro.2015.01.403

Scheer, S. D., \& Harrod, N. (2012). The Influence of Competitive Personality Orientation on Adolescent Emotional Intelligence.

Sekaran. (2014). Research Methods for Business.

Sekaran, U. (2003). Research Methods for Business: A Skill-Building Approach (4th ed.). England: John Wiley \& Sons, Inc. https://doi.org/10.13140/RG.2.1.1419.3126

Shahabinasab, A., Pira, E. Y., Kohansal, F., Golpa, S., \& Arminpili, S. (2016). Volume : 02 Issue : 02 Pages: 39-52 Investigate the Effect of Spirituality in Work on Organizational Citizenship Behavior with the Moderating 
Role of Organizational Commitment ( Case Study: Yasouj University Staff ) Abstract: Keywords : Corresponding A, 39-52.

Shropshire, J., \& Kadlec, C. (2012). Where are you going? A comparative analysis of job and career change intentions among USA it workers. Journal of Internet Banking and Commerce, 17(2), 1-20. https://doi.org/10.1002/job

Spitzmuller, M., Van Dyne, L., \& Ilies, R. (2008). Organizational citizenship behavior: A review and extension of its nomological network. The SAGE Handbook of Organizational Behavior: Volume I Micro Approaches. https://doi.org/10.4135/9781849200448

Srithongrung, A. (2011). The Causal Relationships among Transformational Leadership , Organizational Commitment, and Employee Effectiveness The Causal Relationships among Transformational Leadership , Organizational Commitment, and Employee Effectiveness, (November 2014), 37-41. https://doi.org/10.1080/01900692.2011.5699 17

Sugiyono. (2013). EBOOK METODOLOGI PENELITIAN.pdf.

Sumiyarsih, W., Mujiasih, E., \& Ariati, J. (2012). HUBUNGAN ANTARA KECERDASAN EMOSIONAL DENGAN ORGANIZATIONAL BEHAVIOR ( OCB ).

Sumiyati, Masharyono, Ridwan, Kevin. (2016). The Influence of Social Work Environment on Employee Productivity in Manufacturing in Indonesia, 15, 649-652.

Swaminathan, S., \& Jawahar, P. D. (2013). Job satisfaction as a predictor of organizational citizenship behavior: An empirical study. Global Journal of Business Research, 7(1), 71-80.

https://doi.org/10.1145/382084.382875

Syamsul, Sumiyati, Masharyono. (2016). The Effect of Skill Variety, Task Identity , Task Significance, Autonomy and Feedback on Job Performance, 15, 585-588.

Syamsul Hadi Senen \& Nida Triananda. (2016). The Employee Performance Influenced by Communication: a Study of BUMD in Indonesia, 15, 596-598.

Thamrin, H. M. (2017). The Influence of Transformational Leadership and Organizational Commitment on Job Satisfaction and Employee Performance, 3(5),
$146-165$.

https://doi.org/10.7763/IJIMT.2012.V3.299

Trong Tuan, L. (2016). Knowledge Sharing in Public Organizations: The Roles of Servant Leadership and Organizational Citizenship Behavior. International Journal of Public Administration, 692(August), 1-13. https://doi.org/10.1080/01900692.2015.1113 550

Tuan, L. T., \& Behavior, O. C. (2016). Knowledge Sharing in Public Organizations : The Roles of Servant Leadership and Organizational Citizenship Behavior Knowledge Sharing in Public Organizations: The Roles of Servant Leadership, 692(April). https://doi.org/10.1080/01900692.2015.1113 550

Zainal, V. R., Hadad, M. D., \& Ramly, M. (2014). Kepemimpinan dan Perilaku Organisasi. Depok: PT. RajaGrafindo Persada.

Zeinabadi, H. (2010). Job satisfaction and organizational commitment as antecedents of Organizational Citizenship Behavior ( OCB ) of teachers, 5, 998-1003. https://doi.org/10.1016/j.sbspro.2010.07.225

Zellars, K. L., Tepper, B. J., \& Duffy, M. K. (2002). Abusive supervision and subordinates' organizational citizenship behavior. The Journal of Applied Psychology, 87(6), 1068$1076 . \quad$ https://doi.org/10.1037/00219010.87.6.1068 